Studia i Materiały, 2/2016 (22), cz. 2: 131-145

\title{
Pracownik i pracodawca $w$ perspektywie studentów zarządzania - wyzwania dla edukacji menedżerskiej
}

\author{
Agnieszka Postuta*, Anna Pawtowska**
}

\begin{abstract}
Autorki prezentuja wyniki badań nad charakterem relacji między pracodawca a pracownikiem w obszarze zarzadzania. Koncentruja się na analizie postrzegania roli pracodawcy i pracownika przez trzy grupy spoteczne (Kostera, 2012) oraz jego konsekwencji dla kontraktu psychologicznego jako elementu relacji w środowisku pracy (Makin i in., 2000). W badaniu wzięli udziat studenci pierwszego roku studiów licencjackich i ostatniego roku studiów uzupetniajacych na Wydziale Zarzadzania UW oraz pracodawcy. W celu poznania wyobrażeń badanych osób postużono się technika projekcyjna z wykorzystaniem metafor, które następnie poddano interpretacji (Morgan, 2001, Morgan, 1997). Badania wykazaty, że istnieja poważne rozbieżności w postrzeganiu obu ról (pracownika i pracodawcy) w każdej grupie badanych. $W$ artykule pokazano owo zestawienie wyobrażeń $i$ oczekiwań badanych oraz przyczyny dysonansu, podjęto także próbę wyznaczenia potencjalnych kierunków działań naprawczych w ramach edukacji menedżerskiej.
\end{abstract}

Słowa kluczowe: edukacja menedżerska, kontrakt psychologiczny, charakter relacji, metafora, pracownik i pracodawca.

Nadesłany: 20.11.2016 | Zaakceptowany do druku: 16.12.2016

\section{Employee and Employer as Perceived by Management Students - Challenges for Management Education}

This paper presents the results of research on the management education process concerning the employer-employee relationship. The aim of this paper is to analyze a perception of employers' and employees' social roles (Goffman, 1959) by diverse social groups (Kostera, 2012) and its consequences for the psychological contract which is a significant relationships factor in a working environment (Makin, Cooper and Cox, 2000). First-year students, last-year (fifth-year) students from the Faculty of Management (University of Warsaw) and employers took part in our research. In order to recognize ideas of respondents, we have used projection techniques with metaphors (Morgan, 1997) and then interpretation of metaphors followed. Our research indicated a relatively large discrepancy in this area. In conclusions we analyze this collision of respondents' ideas and expectations, causes of this dissonance and we make an effort to set a direction of potential improvements in management education.

\footnotetext{
Agnieszka Postuła - dr, Wydział Zarządzania, Uniwersytet Warszawski.

Adres do korespondencji: Wydział Zarządzania, Uniwersytet Warszawski, ul. Szturmowa 1/3, 02-678 Warszawa; e-mail: apostula@wz.uw.edu.pl.

** Anna Pawłowska - dr, Wydział Zarządzania, Uniwersytet Warszawski.

Adres do korespondencji: Wydział Zarządzania, Uniwersytet Warszawski, ul. Szturmowa 1/3, 02-678 Warszawa; e-mail: annap@wz.uw.edu.pl.
} 
Keywords: management education, psychological contract, type of relationship, metaphor, employee and employer.

Submitted: 20.11.2016 | Accepted: 16.12.2016

JEL: M12, I2, M54

\section{Wyzwania edukacji menedżerskiej}

Współczesna edukacja menedżerska mierzy się obecnie z wieloma wyzwaniami. Studenci wyrażają głośno swoje oczekiwania, uczelnie w różnym stopniu na nie reagują. Zmiany $\mathrm{w}$ obszarze biznesowej edukacji wyższej są wielokierunkowe. Już cztery dekady temu Mintzberg (1973) zauważył i skrytykował tendencję do nadmiernej specjalizacji szkół biznesowych oraz indywidualizację procesu nauczania. Powszechna dostępność studiowania wydaje się osiągać obecnie punkt kulminacyjny. Spadek jakości kształcenia w uczelniach wyższych jest istotnym, trudnym do pominięcia czynnikiem. Wysoka liczba studentów wpływa nie tylko na zmniejszenie jakości, ale również na pogorszenie kontaktu wykładowca-student. Ci ostatni czują się zaniedbani i lekceważeni, co wynika $\mathrm{z}$ bezpośrednich rozmów. Jest to zaledwie kilka $\mathrm{z}$ wielu niekorzystnych zjawisk w obszarze edukacji menedżerskiej, które powodują, że studenci kończą uczelnie, mając fałszywy wizerunek organizacji. Problemem stojącym na przeszkodzie uczelniom menedżerskim w podejmowaniu trafnych decyzji jest również określenie własnej tożsamości. Szkoły czy uczelnie, które przygotowują przyszłych menedżerów do pracy zasadniczo się od siebie różnią. W pewnym uproszczeniu można by zaproponować następujący podział uczelni wyższych w obszarze edukacji menedżerskiej:

- uniwersytety,

- szkoły zarządzania/biznesu/ekonomii,

- szkoły techniczno-zawodowe ${ }^{1}$.

Jak zauważa wielu autorów tekstów i badaczy (Kwiek, 2015; Koźmiński, 2011; Banaszak, 2011), bardzo ważne jest, by uczelnie, niezależnie od profilu, uświadomiły sobie ten stan rzeczy i dostrzegły potrzebę zmian. Niespełnieni studenci, postępujący niż demograficzny i szereg innych czynników zmusiły już wiele prywatnych uczelni biznesowych do podjęcia odpowiednich kroków zaradczych, mających na celu utrzymanie się na rynku szkół wyższych. Można jednak przypuszczać, że są to jedynie działania korygujące pewne stany zagrożenia, które nie mają charakteru konkretnych, przemyślanych strategii. Wśród uczelnianych decydentów najwyraźniej nadal pokutuje przekonanie, że odpowiedź na potrzeby rynku jest wystarczającym działaniem, nadającym właściwy kierunek rozwojowi szkół. Niestety nadchodzące (a także stale zachodzące) zmiany to nie tylko nowe potrzeby rynku. Uczelnie powinny dostrzec, że zmiany są ogromne i akcja naprawcza, mająca na celu jedynie dostosowanie, nie jest wystarczająca dla utrzymania status quo.

Działania uczelni można wytłumaczyć potrzebami studentów. Ostatnio w coraz większym stopniu placówki otwierają się na sugestie studentów i słuchaczy, a następnie - zgodnie z naczelną zasadą rynkową „,nasz klient, nasz pan” - starają się kreować podaż w odpowiedzi na zapotrzebowanie „klientów”. Takie urynkowienie uczelni powoduje, że wiele dotąd sprawnie przebiegajacych procesów akademickich zamiera (Kostera, 2013). Należy do nich podstawowy kontakt studenta z wykładowcą, spotkania studentów (również wykładowców) w małych grupach konwersacyjnych, autorytet nauczyciela akademickiego czy profesora. Obecnie szkoły zarządzania przede wszystkim staraja się być praktyczne, co oznacza wprowadzanie różnych kierunków kształcenia, dostosowanych do wymogów rynku pracy (Shaw, 2013). Część szkół preferuje nauczycieli akademickich, którzy są jednocześnie praktykami mogącymi pokazać studentom tzw. dobre praktyki (good practicies). Część z nich nastawiona jest na szkolenie konkretnych umiejętności menedżerskich oraz pogłębianie i tak już mocno wyspecjalizowanych kierunków. O zgubności tego procesu w dłuższym okresie przestrzegał wspomniany wcześniej klasyk zarządzania H. Mintzberg (1973). Drugim czynnikiem silnie wpływającym na kierunek rozwoju szkół biznesowych jest ich popularyzacja i dostępność. Według A.K. Koźmińskiego (2011) niepokojącym zjawiskiem 
jest rozpowszechnienie kierunków nauczania niezwiązanych już, tak jak wcześniej, bezpośrednio z biznesem. Przedstawiciele profesji takich jak historyk sztuki, kucharz lub rolnik, przychodzą na uczelnie po wiedzę $\mathrm{z}$ obszaru zarządzania w nadziei, że zostaną lepszymi przedsiębiorcami i menedżerami. Początkowo edukacja menedżerska była skierowana do pracowników wielkich korporacji, w tej chwili wiele uczelni oferujących kierunki biznesowe o niszowych nazwach nie do końca potrafi określić swojego odbiorcę/słuchacza/studenta. Często skutkuje to niedopasowaniem oferty uczelni do studentów oraz niezadowoleniem tych ostatnich.

Jedna z miar sukcesu uczelni jest zatrudnialność (employability) jej absolwentów. Niniejszy artykuł ma na celu wskazanie obszarów niedostosowania wyobrażeń studentów do realiów rynkowych (wyobrażeń pracodawców). Podjęto w nim próbę odpowiedzi na pytanie, jak postrzegana jest rola pracownika i pracodawcy przez studentów oraz czy można wymodelować proces edukacji tak, aby obu stronom ułatwić wzajemne porozumienie i podejmowanie działań sprzyjających realizacji celów biznesowych

\section{Cel i metodologia badań - kontrakt psychologiczny między pracownikiem a przełożonym}

Jednym z zadań edukacji menedżerskiej jest przekazywanie wiedzy i kształtowanie wyobrażeń studentów na temat tego, jakie reguły i zasady obowiązują w miejscu pracy. Służy to przygotowywaniu absolwentów do występowania $\mathrm{w}$ roli pracownika i menedżera tak, aby potrafili efektywnie realizować cele organizacji, na rzecz której pracują. Na ten aspekt funkcjonowania w pracy składają się między innymi relacje między pracownikiem a przełożonym. Jeśli wyobrażenia jednostek, dotyczące tych relacji są zgodne z rzeczywistością i mają charakter proefektywnościowy, to można uznać, iż edukacja dobrze przygotowuje nowych menedżerów do rynku pracy.

Celem prezentowanych badań było więc sprawdzenie, jakie wyobrażenia o relacjach między pracownikiem a podwładnym posiadają studenci kierunku menedżerskiego. Ponadto starano się ustalić, czy proces edukacji kształtuje te wyobrażenia i przygotowuje studentów do efektywnego funkcjonowania na rynku pracy.
Dla potrzeb realizacji postawionego celu badawczego przyjęto, że charakter relacji między pracodawcą a pracownikiem wynika z kontraktu psychologicznego. Po raz pierwszy tego pojęcia użył Chris Argyris (1960), a na gruncie teorii organizacji Edgar Schein (cyt. za: Adamska, 2011). Dla potrzeb prezentowanych badań przyjęta została definicja Denise Rousseau i Martina Grellera, według której „na kontrakt psychologiczny składają się wyobrażenia pracowników dotyczące oczekiwań, jakie ma wobec nich pracodawca oraz spodziewane reakcje pracodawcy na zachowania pracowników" (Wellin, 2010). Ważne jest to, że „oczekiwany przez ludzi sposób traktowania oraz to, jak w rzeczywistości są traktowani, może mieć bardzo istotny wpływ na sposób wykonywania pracy" (Makin i in., 2000).

Aby realizować postawione cele badawcze, zanalizowano kontrakty psychologiczne osób:

- rozpoczynających edukację menedżerską

- kończących proces edukacji

- przedsiębiorców-pracodawców.

Dzięki temu uzyskano odpowiedzi na następujące pytania:

- Czy edukacja menedżerska oddziałuje na elementy składające się na kontrakt psychologiczny?

- Czy edukacja menedżerska kształtuje treści kontraktów psychologicznych zgodnie z oczekiwaniami pracodawców? Powstaje jednak pytanie, jak diagnozować kontrakt psychologiczny. Adamska (2011) proponuje kwestionariusz do badań ilościowych. Postawiony w niniejszym opracowaniu problem badawczy posiada jednak kilka cech, które powodują, że podejście ilościowe do badania może nie dać wiarygodnych wyników. Problem relacji między przełożonym a podwładnym ma charakter bardzo subiektywny i jest obciążony potrzebą aprobaty społecznej. Ponadto istnieje ryzyko udzielania przez osoby badane odpowiedzi zgodnych ze stereotypowymi, obiegowymi poglądami, niekoniecznie zgodnymi z tym, co myślą sami. Ponadto wiele aspektów relacji jest nieuświadomionych i trudnych do zwerbalizowania.

Dlatego w prezentowanym procesie badawczym zastosowano wykorzystywaną w diagnostyce psychologicznej jakościową metodę o charakterze projekcyjnym. Według Sęk metody projekcyjne pokazują 
„subiektywny i podmiotowo-indywidualny sposób odbioru i konstruowania otoczenia", czyli to, co jest potrzebne w analizowanym problemie. Kowalik zwraca natomiast uwagę, że techniki projekcyjne mogą w różnym stopniu powodować wystąpienie zjawiska projekcji. W kontakcie z bodźcem projekcyjnym „może dojść do projekcji treści nieuświadomionych lub maskowanych, lub prostej ekspresji świadomych i akceptowanych treści psychicznych." Zastosowanie metod projekcyjnych do diagnozy przekonań i wyobrażeń co do relacji między przełożonym a podwładnym zakłada proste odwzorowanie poznawczej reprezentacji tego świata w odpowiedzi na bodziec projekcyjny. Ma to tę zaletę, że „materiał projekcyjny w większym stopniu niż materiał jednoznacznie ustrukturalizowany [...] daje lepszy wgląd w fenomenologiczny świat jej [jednostki] przeżyć, pozwala rozpoznać jej osobiste wzorce strukturalizowania i komunikowania doświadczenia, ujawnia dominujący domyślny kontekst społeczny jej działań." Ponieważ chodzi tu o zdiagnozowanie wyobrażonej rzeczywistości sytuacji pracy, mamy do czynienia $z$ innym zastosowaniem tej metody niż to ma miejsce w psychologii klinicznej, gdzie dąży się do uchwycenia mechanizmów obronnych jednostki.

Jako bodziec projekcyjny w prezentowanych badaniach wykorzystano metafore zwierzęcia ${ }^{2}$. Zakłada się tu, że jednostka opisując relacje metaforycznie, projektuje czyli rzutuje swoje przekonania na ten temat zgodnie $\mathrm{z}$ treściami zawartymi w jej strukturach poznawczych ${ }^{3}$. Pozwala to na poznanie tego, co na ten temat rzeczywiście myśli. Dlatego w prezentowanych badaniach jednostki podawały metafory, które im się skojarzyły jako te, które najlepiej opisują pracownika i pracodawcę. Jest to ich spontaniczna reakcja. Zadanie pytania wprost mogłoby wzbudzić w nich obawy przed oceną. Posługując się metaforą, czuja się bezpieczniej, ale także łatwiej jest im przekazać swoje wyobrażenie w kwestiach trudnych do nazwania. Wydaje się, że pytanie osób badanych o relacje w pracy należy do kategorii trudnych psychologicznie i wymagających takiego właśnie podejścia ${ }^{4}$.

Należy wyraźnie podkreślić, że jest to inne zastosowanie metafory niż to ma miejsce w klasycznych badaniach etnograficznych (por. Kostera, 2003). W tym przypadku metafora służy odwzorowaniu rzeczywistości w celu ułatwienia zrozumienia mechanizmów zgodnie, z którymi ona działa.

$\mathrm{Na}$ bazie przedstawionego podejścia badawczego skonstruowano narzędzie diagnostyczne Test Metafor, w którym osoby badane wykonywały następujące polecenia: - Porównaj pracownika do zwierzęcia. Pracownik jest jak... Uzasadnij odpowiedź.

- Porównaj przełożonego do zwierzęcia. Przełożony jest jak... Uzasadnij odpowiedź.

Badani przedsiębiorcy-pracodawcy udzielali odpowiedzi tylko na pierwsze polecenie. Pominięto wyobrażenia dotyczące pracodawców, gdyż analiza ich identyfikacji z tą rolą nie jest przedmiotem zainteresowania niniejszego opracowania.

$\mathrm{Na}$ podstawie uzyskanych odpowiedzi osób badanych opisano kontrakty psychologiczne preferowane przez poszczególne grupy badane, a następnie przeprowadzono ich analizę porównawczą. Analiza wyników odbywała się zgodnie z sugestią K.J. Mc Innisa, J.P. Meyera i S. Feldmana (2009). Według nich kontrakt psychologiczny powinien być analizowany pod względem treści (relacyjny lub transakcyjny), oceny emocji (pozytywne-negatywne) oraz charakteru relacji (na przykład jej asymetryczność). W szczególności, jeśli chodzi o treść zbadano, czy osoby badane oczekują kontraktu relacyjnego, który obejmuje nastawienie na długoterminowe zatrudnienie i zaspokajanie wzajemnych potrzeb, a główne wartości to lojalność i stabilność. Relacje w tym przypadku na ogół są paternalistyczne. Innym rodzajem może być kontrakt psychologiczny transakcyjny, kiedy to między pracodawcą a pracownikiem dochodzi do paraekonomicznej wymiany świadczeń w ramach ściśle określonego zakresu powinności i zadań obu stron, a relacje są partnerskie.

$\mathrm{Na}$ bazie metafor podawanych przez osoby badane zdiagnozowano kontakty psychologiczne opisane pod względem wyżej wymienionych elementów.

Zgodnie z zaprezentowanym schematem w badaniach wzięły udział trzy grupy:

- Grupa rozpoczynająca proces edukacji menedżerskiej: studenci pierwszego roku studiów licencjackich, miejsce: Wydział Zarządzania UW, czas: październik 2013, liczba osób poddanych badaniu: 32 . 
- Grupa kończąca proces edukacji menedżerskiej: studenci ostatniego roku studiów magisterskich, miejsce: Wydział Zarządzania UW, czas: październik 2013, liczba osób poddanych badaniu: 35 .

- Grupa pracodawców: przedsiębiorcy, miejsce: Wydział Zarządzania UW, studia podyplomowe EFS, czas: styczeń 2012; liczba osób poddanych badaniu: 31 .

\section{Wyniki badań}

Wyniki badań w postaci cytatów odpowiedzi udzielonych przez osoby badane w Teście Metafor, zostały zestawione w tabelach 1-5 w dosłownym ich brzmieniu. Zgodnie z wytycznymi metodologicznymi, dotyczącymi sposobu analizy materiału projekcyjnego, jakiekolwiek zmiany i poprawki, np. językowe, nie moga mieć miejsca, gdyż byłoby to zniekształcanie materiału badawczego i tym samym obniżenie rzetelności jego analizy.

W tabelach zawarto też informację, ile osób wskazało danego rodzaju metaforę, a w nawisach kwadratowych znajdują się numery osób badanych, które udzieliły cytowanej odpowiedzi. W dalszej części znajdują się opisy kontraktów psychologicznych, które wynikają z analizy podanych przez osoby badane metafor.

Tabela 1. Metafory pracownika wymienione przez osoby badane z grupy rozpoczynającej proces edukacji menedżerskiej (studenci pierwszego roku); cytaty

\begin{tabular}{|c|c|c|}
\hline $\begin{array}{l}\text { Wymienione } \\
\text { metafory }\end{array}$ & $\begin{array}{c}\text { Liczba } \\
\text { wskazań }\end{array}$ & Uzasadnienie \\
\hline Mrówka & 9 & $\begin{array}{l}\text { - jest pracowity, działa w grupie [2] } \\
\text { - pracuje dla siebie i dla królowej (pracownik zarabia na siebie, } \\
\text { ale i dla pracodawcy) [3] } \\
\text { - musi być potulny [6] } \\
\text { - pracowita, pracowite zwierze [11] } \\
\text { - stereotypowy pracownik - robot korporacji [13] } \\
\text { - ciągle zajęta, nie ma umiejętności, ale robi dobrą pracę [21] } \\
\text { - nie pyta, po prostu wykonuje swoją pracę, działa sama i wrupie [22] }\end{array}$ \\
\hline Owca & 4 & $\begin{array}{l}\text { - nigdy nie wie, czy może być spokojna, czy ktoś jej nie zaatakuje } \\
\text { (̇̇yje w strachu) [7] } \\
\text { - jest częścią większej społeczności [23] }\end{array}$ \\
\hline Pies & 3 & $\begin{array}{l}\text { - smuci się, jak go ktoś okrzyczy, cieszy się, gdy dostanie nagrodę [8] } \\
\text { - jak się go dobrze wytresuje, to się słucha [9] }\end{array}$ \\
\hline Leniwiec & 3 & bywa leniwy i mało przydatny [12] \\
\hline Mysz & 2 & musi być potulna [10] \\
\hline Wół & & dużo pracuje [4] \\
\hline Osioł & 1 & ciężko pracuje, ale czasami ciężko go zmotywować [5] \\
\hline Rybka & 1 & jest ich dużo i robią mało przydatne rzeczy [14] \\
\hline Legwan & 1 & „obija się” [18] \\
\hline Pszczoła & 1 & powinien być pracowity [1] \\
\hline Małpa & 1 & brak \\
\hline Panda & 1 & brak \\
\hline Szympans & 1 & brak \\
\hline Antylopa & 1 & brak \\
\hline Koń pociągowy & 1 & brak \\
\hline Zebra & 1 & brak \\
\hline Kot & 1 & brak \\
\hline
\end{tabular}

Źródło: opracowanie własne na podstawie wyników badania Testem Metafor. 
Tabela 2. Metafory pracodawcy wymienione przez osoby badane z grupy rozpoczynającej proces edukacji menedżerskiej (studenci pierwszego roku); cytaty

\begin{tabular}{|l|c|l|}
\hline $\begin{array}{l}\text { Wymienione } \\
\text { metafory }\end{array}$ & $\begin{array}{c}\text { Liczba } \\
\text { wskazań }\end{array}$ & \\
\hline Lew & 15 & $\begin{array}{l}\text { - powinien być doskonałym przywódcą [1] } \\
- \text { kojarzy się z dowódca, jest dominujący [3] } \\
- \text { wydaje się groźny [6] } \\
\text { - jeśli trzeba, jest sprawiedliwy, ale może też się wkurzyć; uchodzi za } \\
\text { władcę [7] } \\
- \text { zjada najsłabszych [8] } \\
- \text { sprawuje władzę i podejmuje decyzje [10] } \\
- \text { silny charakter, ma autorytet w grupie [13] } \\
- \text { przewodzi stadu (firmie), ma respekt [14] } \\
- \text { król dżungli [18] [20] }\end{array}$ \\
\hline Sęp & 2 & bywa bardzo pazerny [12] \\
\hline Tygrys & 2 & Brak \\
\hline Wilk & 2 & Brak \\
\hline Niedźwiedź & & jest potężny, działa sam, rzadko pokazuje się publicznie [2] \\
\hline Świnia & & jest bezwzględny, zwalnia ludzi, mało płaci [4] \\
\hline Lis & & pozornie miłe zwierzątko, ale trzeba na nie uważá [5] \\
\hline Hipopotam & & zatrudnia ptaki, które o niego dbają [11] \\
\hline Sowa & symbol inteligencji, dobry łowca [19] \\
\hline Słoń & $\begin{array}{l}\text { solidny, stabilny, powolny, ale prze do celu; pamiętliwy, pamiętający } \\
\text { [21] }\end{array}$ \\
\hline Lampart & Brak \\
\hline Buldog & Brak \\
\hline Hiena & Brak \\
\hline
\end{tabular}

Źródło: opracowanie własne na podstawie wyników badania Testem Metafor.

\subsection{Kontrakt psychologiczny - grupa rozpoczynająca proces edukacji menedżerskiej}

\subsubsection{Zawartość kontraktu psychologicznego}

W metaforach studentów pierwszego roku w pierwszej kolejności zwraca uwage niewielka liczba uzasadnień wskazanych skojarzeń w porównaniu z pozostałymi grupami badanymi. Można przypuszczać, że prawdopodobnie wynika to $\mathrm{z}$ faktu, iż nie posiadają jeszcze rozbudowanej reprezentacji poznawczej pracownika i pracodawcy $\mathrm{z}$ uwagi na brak doświadczenia zawodowego. Ich poglądy przypuszczalnie ukształtowały przekazy członków rodziny i znajomych. Wypowiedzi tej grupy studentów stanowią więc raczej podstawę do obserwacji kulturowo zdeterminowanych wyobrażeń na temat relacji w środowisku pracy, jakie otrzymują młodzi ludzie. Te wyobrażenia są podstawą dalszego ich kształtowania w procesie edukacji i zdobywania doświadczenia w realnej sytuacji. Sa to jednak tylko przypuszczenia, które powinny być poddane dalszym, bardziej pogłębionym badaniom.

Uzyskany materiał projekcyjny dotyczacy wyobrażenia pracownika zawiera elementy zarówno relacyjnego, jak i transakcyjnego kontraktu. Przedmiotem wymiany w relacji pomiędzy pracownikiem a pracodawcą jest ciężka praca, raczej „bezmyślna” i bardziej w rozumieniu wysiłku fizycznego niż intelektualnego [1, 4, 5, 11, 13, 14, 21]. W aspekcie relacyjnym akcentuje się przynależność do grupy, co wynika z potrzeby ochrony (metafora owcy) [7, 23,]. 
Natomiast w wyobrażeniach dotyczących pracodawcy wyraźnie ujawnia się kontrakt relacyjny. Badani akcentują fakt, że ma on władzę, siłę i decyduje o wszystkim, a nawet „zjada najsłabszych” [8]. Jest przywódcą inteligentnym, który dobiera sobie pracowników tak, aby o niego dbali $[19,11]$.

\subsubsection{Ocena emocji}

W metaforach studentów pierwszego roku zauważa się emocje wynikające z zależności pracownika od pracodawcy, który „wydaje się groźny” [6]. Kontakt Z przełożonym kojarzy się z negatywnymi emocjami (w metaforze owcy [7, 23]). Pojawia się obawa, ,że ktoś [pracownika] okrzyczy" [8] oraz oczekiwanie nagrody w trakcie „tresury” [9]. Zadowalanie przełożonegowładcy to główne zadanie pracownika, choć pracownik „bywa też leniwy i mało przydatny" [12].

\subsubsection{Cechy relacji}

W metaforach studentów pierwszego roku mamy do czynienia $\mathrm{z}$ wyraźnie asymetryczną relacją pracownik-przełożony. Przełożony to raczej samotnik utrzymujący duży dystans, oceniający i wymagajacy [2]. Pracownik jest podporządkowany i powinien być posłuszny [6, 10], a jeśli może sobie na to pozwolić, bywa leniwy i ignoruje oczekiwania przełożonego[12, 18]. Jest to rodzaj „układu”, który jest czymś naturalnym w środowisku pracy. Reguły paternalistyczne obowiązują obie strony [3, 14, $18,20]$. Jedynie w wypowiedziach dotyczących pracowników pojawiają się elementy wymiany typowe dla kontraktu transakcyjnego $[2,3]$, ale są trudne do zrealizowania w środowisku pracy. Jest to bowiem przywództwo oparte bardziej na straszeniu, niż na wsparciu, czy rzeczowej wymianie wzajemnych świadczeń. [4]

Tabela 3. Metafory pracownika wymienione przez osoby badane z grupy kończącej proces edukacji menedżerskiej (studenci ostatniego roku); cytaty

\begin{tabular}{|c|c|c|}
\hline $\begin{array}{l}\text { Wymienione } \\
\text { metafory }\end{array}$ & $\begin{array}{c}\text { Liczba } \\
\text { wskazań }\end{array}$ & Uzasadnienie \\
\hline Mrówka & 8 & $\begin{array}{l}\text { - ciężko haruje, ogrom pracy [2] } \\
\text { - pracowitość, praca zespołowa [7] } \\
\text { - dzień w dzień musi umacniać firmę, w której jest zatrudniona, tak jak } \\
\text { mrowisko [11] } \\
\text { - pracuje w zespole dla dobra ogółu [19] } \\
\text { - oddany pracy, spełniający się, ambitny i pracowity [20] } \\
\text { - robi to, co musi, czasem nawet bezmyślnie wypełnia postawione przed } \\
\text { nią zadania [29] } \\
\text { - odnosi się do korporacji, zna swoje miejsce w organizacji i ciężko } \\
\text { pracuje [31] }\end{array}$ \\
\hline $\begin{array}{l}\text { Mysz (szara } \\
\text { mysz) }\end{array}$ & 3 & $\begin{array}{l}\text { - spokojny, zajęty swoimi sprawami, ostrożny [5] } \\
\text { - pracownicy korporacji - wykonują swoja pracę według wytycznych } \\
\text { [23] } \\
\text { - zwierzę spokojne, zajęte swoimi sprawami, jednocześnie ostrożne [27] }\end{array}$ \\
\hline Pies & 3 & $\begin{array}{l}\text { - dobrze traktowany jest najlepszym przyjacielem, ale może tez być } \\
\text { ukrytym wrogiem [8] } \\
\text { - w zamian za wynagrodzenie darzy pracodawcę poważaniem } \\
\text { i wdzięcznością, podporządkowuje mu się [30] } \\
\text { - wierny i lojalny z przymusu; lubi być chwalony [32] }\end{array}$ \\
\hline Antylopa & 2 & $\begin{array}{l}\text { - ofiara, bezbronna, delikatna, ufna, wzbudza litość, potrzebuje ochrony } \\
\text { [14] } \\
\text { - stale zagrożona, zwinna i szybka, dostosowuje się [16] }\end{array}$ \\
\hline Szczur & 2 & $\begin{array}{l}\text { - analogia do „wyścigu szczurów” - ciągła pogoń za pieniędzmi, } \\
\text { karierą [17] } \\
\text { - musi walczyć o swoje często kosztem innych, nieustanna } \\
\text { rywalizacja [25] }\end{array}$ \\
\hline
\end{tabular}

Wydział Zarządzania UW ～DOI 10.7172/1733-9758.2016.22.10 
Tabela $3 \mathrm{~cd}$.

\begin{tabular}{|l|c|l|}
\hline $\begin{array}{c}\text { Wymienione } \\
\text { metafory }\end{array}$ & $\begin{array}{c}\text { Liczba } \\
\text { wskazań }\end{array}$ & \multicolumn{1}{c|}{ Uzasadnienie } \\
\hline Małpy & 2 & $\begin{array}{l}\text { - żyją stadnie, każda zna swoją pozycję w stadzie, mają przywódcę, } \\
\text { określone prawa i przywileje [18] } \\
\text { - wykonuje pracę dla pensji (banana), czasem ślepo podąża za } \\
\text { pieniędzmi [10] }\end{array}$ \\
\hline Pszczoła & 2 & $\begin{array}{l}\text { - pracowita, poświęca większość życia na pracę dla dobra organizacji [3] } \\
- \text { musi odnaleźć się w grupie, ma określoną rolę i pracę do wykonania, } \\
\text { przeważnie jest pracowita i lojalna [24] }\end{array}$ \\
\hline Osioł & 2 & $\begin{array}{l}\text { - obarczany mnóstwem zadań, wykorzystywany przez tych, co są wyżej [26] } \\
\text { - nie potrafi samodzielnie funkcjonować w pracy, często podejmuje złe, } \\
\text { nielogiczne decyzje [33] }\end{array}$ \\
\hline Leniwiec & 2 & $\begin{array}{l}\text { - robi wszystko, żeby się nie napracować [6] } \\
- \text { zbyt duża część pracowników myśli o tym, jak się nie narobić, a zaro- } \\
\text { bić - unikają wysiłku intelektualnego, fizycznego i zaangażowania [22] }\end{array}$ \\
\hline Owieczka & $\begin{array}{l}\text { uległy, posłuszny wobec szefa, wykonuje polecenia, nie wyróżnia się } \\
\text { w grupie [21] }\end{array}$ \\
\hline Kangur & $\begin{array}{l}\text { żyje w stadzie, mierzy się z wyzwaniami („,boksowanie” kangura), } \\
\text { outsider z innej planety (kontynentu), nosi swoje zadania przy sobie } \\
\text { (torba), jest za nie odpowiedzialny [9] }\end{array}$ \\
\hline Cielak & mało mówi, dużo pije, by być zadowolony [13] \\
\hline Kameleon & $\begin{array}{l}\text { dostosowuje się do otoczenia, na które zazwyczaj nie ma większego } \\
\text { wpływu; wywiązuje się ze swoich obowiązków, ale nie wyróżnia się [12] }\end{array}$ \\
\hline Zając & sprytny [28] \\
\hline
\end{tabular}

Źródło: opracowanie własne na podstawie wyników badania Testem Metafor.

Tabela 4. Metafory pracodawcy wymienione przez osoby badane z grupy kończącej proces edukacji menedżerskiej (studenci ostatniego roku); cytaty

\begin{tabular}{|c|c|c|}
\hline $\begin{array}{l}\text { Wymienione } \\
\text { metafory }\end{array}$ & $\begin{array}{c}\text { Liczba } \\
\text { wskazań }\end{array}$ & Uzasadnienie \\
\hline Lew & 11 & $\begin{array}{l}\text { - zwierzę, które stoi na czele stada; cechy pracodawcy to m.in.: } \\
\text { przywództwo, zarządzanie innymi, głowa firmy, jednostkowe } \\
\text { podejście do systemu, dążenie po trupach do celu [7] } \\
\text { - odpowiada za resztę stada, rozwiązuje problemy, korzysta z pracy } \\
\text { innych [8] } \\
\text { - musi cały czas walczyć o utrzymanie się na rynku i przedzierać przez } \\
\text { dżunglę przepisów [11] } \\
\text { - król wszystkich zwierząt, zawsze trzeba się go słuchać, posiada władzę } \\
\text { oraz wiedzę i doświadczenie, które potrafi przekazać innym [17] } \\
\text { - symbolizuje siłę, silny, groźny, ale też uległy [18] } \\
\text { - dba o firmę, walczy z przeciwnościami, musi nadzorować pracowników } \\
\text { [19] } \\
\text { - ma władzę, inni się do niego dostosowują, boją się go [20] } \\
\text { - ma władzę, jest pewny siebie, wszyscy są mu posłuszni, ulegli wobec } \\
\text { niego; ma autorytet [21] } \\
\text { - król na rynku pracy [22] } \\
\text { - panuje nad pracownikami, którzy darzą go szacunkiem [30] } \\
\text { - przywódca, kierownik, szef [32] }\end{array}$ \\
\hline
\end{tabular}


Tabela $4 \mathrm{~cd}$.

\begin{tabular}{|c|c|c|}
\hline $\begin{array}{l}\text { Wymienione } \\
\text { metafory }\end{array}$ & $\begin{array}{c}\text { Liczba } \\
\text { wskazań }\end{array}$ & Uzasadnienie \\
\hline Lis & 4 & $\begin{array}{l}\text { - przebiegły [1] } \\
\text { - przebiegły, robi wszystko, żeby wypaść lepiej w porównaniu z innymi [6] } \\
\text { - przebiegły i zwinny, stara się, by nie przegrać walki o sukces z innymi; } \\
\text { chytry [25] } \\
\text { - przebiegły względem procedur [33] }\end{array}$ \\
\hline Rekin & 3 & $\begin{array}{l}\text { - rządzi w organizacji, żywi się mniejszymi „rybami” - wykorzystuje } \\
\text { pracowników [16] } \\
\text { - bezwzględny, drapieżny [26] }\end{array}$ \\
\hline Tygrys & 2 & $\begin{array}{l}\text { - waleczny, szybki, gdy trzeba potulny, podejmuje szybkie decyzje [13] } \\
\text { - czuje władzę, jest jej świadomy, silny, niebezpieczny, pewny siebie, } \\
\text { wzbudza strach, zawsze zwycięża [14] }\end{array}$ \\
\hline Kot & 2 & $\begin{array}{l}\text { - nie docenia osób, które się nim zajmują (dla niego pracują), zawsze } \\
\text { domaga się więcej i szybciej; nieprzewidywalny [3] } \\
\text { - lubi siedzieć, nic nie chce robić; niby łagodny, ale często wredny [5] }\end{array}$ \\
\hline Słoń & 1 & $\begin{array}{l}\text { - widoczny punkt w organizacji, dużo w niej znaczy, nie ma sobie } \\
\text { równych, przecenia możliwości swoje i pracowników, jest za bardzo } \\
\text { ambitny [15] }\end{array}$ \\
\hline Baran & 1 & $\begin{array}{l}\text { - nie głupota, ale nieobliczalność; uparty, cechuje go stanowcza } \\
\text { postawa, groźny, pewny siebie [2] }\end{array}$ \\
\hline Pająk & 1 & $\begin{array}{l}\text { - dba o pajęczynę (przedsiębiorstwo), buduje kolejne jej elementy, } \\
\text { „poluje” na klientów [9] }\end{array}$ \\
\hline Niedźwiedź & 1 & $\begin{array}{l}\text { - władczy, czasem wykorzystuje swoje przywileje i swoje mocne strony, } \\
\text { czasem wyleguje się jak niedźwiedź w zimie [10] }\end{array}$ \\
\hline Sroka & 1 & $\begin{array}{l}\text { - patrzy na wszystkich z góry, jest czujnym obserwatorem, potrafi } \\
\text { unieść głos; jak tylko dostrzeże błyskotliwą ideę, zaraz chce wejść } \\
\text { w jej posiadanie, zabiera, co jest do wzięcia [12] }\end{array}$ \\
\hline Koń & 1 & $\begin{array}{l}\text { - silny charakter, duża wytrzymałość, niezależność oraz przysłowiowe } \\
\text { końskie zdrowie [24] }\end{array}$ \\
\hline Jastrząb & 1 & $\begin{array}{l}\text { - zwierzę z godnością, nieosiągalne, obserwuje wszystko z góry, czuwa; } \\
\text { jest sprytny i zwinny [27] }\end{array}$ \\
\hline Żyrafa & 1 & - ma długą szyję i wszystko widzi [28] \\
\hline Nietoperz & 1 & - niedowidzi, niedosłyszy, a wszystkiego się czepia [29] \\
\hline Kruk & 1 & - pojawia się i dziobie lub daje o sobie znać gdzieś „w tle” [31] \\
\hline
\end{tabular}

Źródło: opracowanie własne na podstawie wyników badania Testem Metafor.

\subsection{Kontrakt psychologiczny - grupa kończąca proces edukacji menedżerskiej}

\subsubsection{Zawartość kontraktu psychologicznego}

Zdecydowanie wyraźniejsze poglądy na temat relacji pracownik-przełożony mają studenci ostatniego roku studiów magisterskich, o czym może świadczyć znacznie większa liczba uzasadnień wybranych metafor. W ich metaforach przełożony jest już wyraźnie postacia negatywna. Jest niebezpieczny, groźny [16, 26, 14, 2, 27, 31]. Działa kosztem innych, zwłaszcza słabszych, wymaga posłuszeństwa. Dba o firmę, jest autorytetem, ale budzi również strach. Musi nadzorować pracowników i „wszystkiego się czepia" [29]. Bywa leniwy, ale i waleczny oraz silny $[18,14]$. Kilkakrotnie pojawia się jego skłonność do patrzenia „z góry” [28, 12]. W zasadzie przełożony nic nie oferuje pracownikom, „nie docenia osób, które się nim zajmują (dla niego 
pracują), zawsze domaga się więcej i szybciej". [3]

Do opisu pracowników studenci wykorzystują zwierzęta niedojrzałe, jak na przykład cielak [13] czy owieczka [21] lub istoty niewielkie, pozbawione znaczenia - jak mysz $[5,23,27]$. Sugeruje to ich bezbronność i zależność od silniejszego, dominującego pracodawcy. Ten charakter relacji szczególnie podkreśla uzasadnienie metafory antylopy - „ofiara, bezbronna, delikatna, ufna, wzbudza litość, potrzebuje ochrony" [14]. Wyraźnie sugeruje to relację typu rodzic-dziecko i kontrakt psychologiczny o charakterze relacyjnym (paternalistycznym). W wyobrażeniach studentów ostatniego roku pracownik $\mathrm{w}$ relacji $\mathrm{z}$ przełożonym to jednostka posłuszna i podporządkowana.

\subsubsection{Ocena emocji}

W metaforach studentów występują elementy świadczące o negatywnym nastawieniu do przełożonego, ale wynika ono z charakteru nierównorzędnej relacji podległości. Pracownik metaforycznie opisywany jako pies „dobrze traktowany jest najlepszym przyjacielem, ale może też być ukrytym wrogiem" [8].

Nie przewiduje się łamania reguł umowy zawartej w kontrakcie psychologicznym między pracownikiem a przełożonym. „Żyją stadnie, każda strona zna swoją pozycję w stadzie, mają przywódce, określone prawa i przywileje" [18]. W uzasadnieniach metafor podawanych przez studentów świat pracy, oparty na wspomnianych zasadach, wydaje się jawić jako coś naturalnego i niekwestionowalnego.

\subsubsection{Cechy relacji}

$\mathrm{Z}$ metafor podawanych przez studentów kończących edukację menedżerską wynika, że relacje mają wyraźnie charakter asymetryczny - na korzyść pracodawcy. Wynika to jednak z charakteru sytuacji, w której jest przywódca i podążające za nim „stado”. Ta asymetria nie budzi silnego buntu, czy sprzeciwu u studentów. W ich przekonaniu przełożony jakby w naturalny sposób oczekuje posłusznego wykonywania jego poleceń i lojalności [21, 22, 30, 32].

Tabela 5. Metafory pracownika wymienione przez pracodawców; cytaty

\begin{tabular}{|c|c|c|}
\hline $\begin{array}{l}\text { Wymienione } \\
\text { metafory }\end{array}$ & $\begin{array}{c}\text { Liczba } \\
\text { wskazań }\end{array}$ & Uzasadnienie \\
\hline pies & 7 osób & $\begin{array}{l}\text { - wierny, ciężko pracuje, jest uwiązany przez pracodawcę, cierpliwie } \\
\text { czeka na miskę - ale zwykle dostaje mało i to z dużym opóźnieniem } \\
\text { albo nic, ale jak się wkurzy, to ugryzie! [1] } \\
\text { - posłuszny, wykonuje polecenie, czeka na wypłatę jak na wyjście na } \\
\text { spacer [5] } \\
\text { - przywiązanie/lojalność (pożądani) [8] } \\
\text { - nie wychyla się ze swoimi pomysłami, wykonuje polecenia szefa, } \\
\text { często bezmyślnie [9] } \\
\text { - przyjazny, zna swoje miejsce, lojalny wobec pracodawcy [22] } \\
\text { - lojalny [26] }\end{array}$ \\
\hline leniwiec & 6 & $\begin{array}{l}\text { - powolny i bierny [15] } \\
\text { - przeciętnego pracownika trzeba pilnować i zmobilizować [20] } \\
\text { - czy się stoi, czy się leży... [21] } \\
\text { - nie muszę włożyć więcej od wymagań [27] } \\
\text { - brak uzasadnienia }\end{array}$ \\
\hline kot & 3 & $\begin{array}{l}\text { - leniwy, czeka na gotowe, chodzi własnymi drogami, a jest miły, kiedy } \\
\text { ma w tym interes [10] } \\
\text { - umiejętnie podąża za swoim właścicielem, jednocześnie w każdej } \\
\text { chwili może pójść w swoją stronę, gdy mu się odwidzi [13] } \\
\text { - jest sprytny, dopasowuje się do otoczenia, odpowiednio umie zadbać } \\
\text { o względy przełożonych [30] }\end{array}$ \\
\hline wilk & 2 & $\begin{array}{l}\text { - członek watahy (nie alfa, tylko niższe szczeble); może awansować, } \\
\text { a nawet do szczebla alfa, ale na razie jest raczej niżej w hierarchii; } \\
\text { odgrywa swoją role pod przewodnictwem samca alfa [2] } \\
\text { - wartość, chciwość, czujny, jaki powinien być: bogobojny [19] }\end{array}$ \\
\hline
\end{tabular}


Tabela $5 \mathrm{~cd}$.

\begin{tabular}{|c|c|c|}
\hline $\begin{array}{l}\text { Wymienione } \\
\text { metafory }\end{array}$ & $\begin{array}{c}\text { Liczba } \\
\text { wskazań }\end{array}$ & Uzasadnienie \\
\hline owca & 2 & $\begin{array}{l}\text { - potrzebuje swojego pasterza [11] } \\
\text { - trzeba sprowadzić ją do stada i sprawić, żeby czuła się w nim dobrze, } \\
\quad \text { a zarazem przynosiła efekty dla pasterza i innych w stadzie [12] }\end{array}$ \\
\hline zając & 2 & $\begin{array}{l}\text { - płochliwy, niepewny siebie, bojący się [17] } \\
\text { - jeden z wielu, zastraszony [23] }\end{array}$ \\
\hline kameleon & 1 & - zmienia się w zależności od potrzeb [4] \\
\hline $\begin{array}{l}\text { bawół } \\
\text { rzeczny }\end{array}$ & 1 & - szuka spokoju, jak zły to niebezpieczny [3] \\
\hline mrówka & 2 & $\begin{array}{l}\text { - funkcjonuje jako jeden z ciężko pracujących trybów bez większych } \\
\text { szans na zmianę [31] } \\
\text { - brak uzasadnienia }\end{array}$ \\
\hline lis & 1 & $\begin{array}{l}\text { - chytry (jak robić, żeby się wyrobić, wyjść na swoje i zarobić); } \\
\text { niekoniecznie pożądany [8] }\end{array}$ \\
\hline osioł & 1 & $\begin{array}{l}\text { - silny, może pracować, ale nie jest kreatywny, wykonuje tylko to, co } \\
\text { mu się każe, czasami uparty i ślepo robiący rzeczy niezrozumiałe [18] }\end{array}$ \\
\hline koń & 1 & - Brak \\
\hline mysz & 1 & - Brak \\
\hline wół & 1 & - Brak \\
\hline $\begin{array}{l}\text { człowiek } \\
\text { - zwierzę } \\
\text { stadne }\end{array}$ & 1 & - wymagające przywódcy i zdefiniowanych reguł [6] \\
\hline to zależy... & 1 & - Brak \\
\hline
\end{tabular}

Źródło: opracowanie własne na podstawie wyników badania Testem Metafor.

\subsection{Kontrakt psychologiczny - grupa} pracodawców

\subsubsection{Zawartość kontraktu psychologicznego}

W metaforach przedsiębiorców-pracodawców akcentowana jest w odniesieniu do pracownika potrzeba przynależności do grupy (stada) [11], kierowanego przez przywódcę (pies, wilk, owca, mrówka). Wskazuje na to ponad połowa badanych (18 osób). Podkreślają oni znaczenie lojalności i wierności oraz posłuszeństwa [1, 8, 22, 26]. Ciężko, poddańczo pracujący pracownik [13,1 8, 31] skontrastowany jest $\mathrm{z}$ leniwym (metafora leniwca $[15,20$, 21, 27]), szukającym sposobu, jak uniknąć pracy $[10,8]$. Identyfikowane są więc u pracowników dwie postawy. Pierwsza sprytnego lenistwa, umiejętności dbania o własny interes (kameleon [4], lis [8]) i potencjalnego buntu, gdy coś nie idzie według ich myśli [3]. Druga zaś to bezrefleksyjne podporządkowanie i lękliwość (zając [17, 23]). Relacja opiera się na zasadzie przywódca-członek stada i w tym sensie jest paternalistyczna. Przedsiębiorcy nie opisują pracowników zdrobnieniami, jak to robią studenci ostatniego roku.

\subsubsection{Ocena emocji}

W ocenie pracodawców pracownicy są postaciami negatywnymi, ale nie wyłącznie. Bywają nawet przyjaźni. Wymieniana przez największą liczbę osób badanych (7) metafora psa ma w sobie odrobinę sympatii i pozytywnego nastawienia. Zakłada się jednak, że kontrakt psychologiczny może nie być przestrzegany przez pracownika, który ,jak się wkurzy, to ugryzie" [1] i jednocześnie w każdej chwili „może pójść w swoją stronę, gdy mu się odwidzi" [13].

\subsubsection{Cechy relacji}

$\mathrm{Z}$ metafor podawanych przez pracodawców wynika, że relacja ma charakter asymetryczny. Pracodawcy akcentują konieczność 
kontrolowania pracownika, bez której ich zdaniem nie ma on motywacji do pracy $[12,20]$. Tym samym sankcjonują swoją rolę przywódcy stada [6]. Pojawiają się w metaforach sygnały, że negatywną cechą pracowników w ocenie pracodawców jest brak samodzielności pracowników - „ślepo robiących rzeczy niezrozumiałe" [18], co sugerowałoby, że oczekują kontraktu psychologicznego transakcyjnego. W metaforach i ich uzasadnieniach nie ma jednak wyraźnego sygnału o potrzebie relacji partnerskiej, która jest właściwa dla tego typu kontraktu. Wręcz przeciwnie, akcentowanie lojalności jest wskazaniem do podtrzymania więzi charakterystycznej dla relacyjnego kontraktu psychologicznego.

\subsection{Analiza porównawcza i odpowiedź na pytania badawcze}

Celem prezentowanych badań było ustalenie, czy edukacja menedżerska oddziałuje na elementy składające się na kontrakt psychologiczny. Odpowiedź na to pytanie uzyskuje się poprzez porównanie odpowiedzi udzielonych w Teście Metafor przez grupy osób rozpoczynających i kończących edukację menedżerską.

W zakresie wszystkich trzech analizowanych elementów kontraktu psychologicznego nie zauważa się wyraźnych różnic między badanymi grupami. Pod względem zawartości kontraktu psychologicznego obie grupy wykazują nastawienie na kontrakt relacyjny, przy czym w grupie kończącej proces edukacji relacje są wyraźnie bardziej paternalistyczne i mamy do czynienia z negatywnym wyobrażeniem pracodawcy. W obu przypadkach także emocje dotyczące relacji są negatywne. Wśród studentów ostatniego roku studiów w metaforach uwidacznia się relacja podległości. Cechą relacji jest jej asymetryczność na korzyść pracodawców. Można odnieść wrażenie, że właśnie taki typ relacji zdaniem badanych jest czymś naturalnym i oczywistym.

Na podstawie wyników badania można przypuszczać, że w procesie edukacji menedżerskiej nie podejmuje się celowych oddziaływań na oczekiwania przyszłych pracowników i menedżerów co do reguł i zasad pracy, składających się na kontrakt psychologiczny. Warto byłoby zweryfikować to ustalenie $\mathrm{z}$ wykorzystaniem innej metody badawczej.

Drugie postawione pytanie badawcze dotyczyło tego, czy edukacja menedżerska kształtuje treści kontraktów psychologicznych zgodnie z oczekiwaniami pracodawców. Analizując treści metafor podawanych przez pracodawców i wynikających $\mathrm{z}$ nich elementów, składających się na kontrakt psychologiczny, można stwierdzić, że nie zauważa się większych odstępstw od tego, co podają studenci. Pracodawcy również wskazują na kontrakt psychologiczny relacyjny, ale zdecydowanie wyraźniej akcentuja takie cechy pracowników, jak lojalność i wierność oraz posłuszeństwo. Emocje ujawniane w metaforach przez pracodawców w odniesieniu do pracowników nie są jednoznacznie negatywne pojawiają się elementy sympatii. Zarzucają oni jednak pracownikom brak samodzielności w działaniu 5 , choć jednocześnie podtrzymują relacje asymetryczne na korzyść pracodawcy.

Wydaje się więc, że studenci mają dość zbliżony do rzeczywistości obraz relacji między pracownikiem a pracodawcą. Trudno jednak na podstawie przeprowadzonych badań jednoznacznie stwierdzić, na ile są one efektem procesu edukacyjnego. Ponadto posiadane przez osoby badane przekonania co do reguł wzajemnych relacji i obowiązujące między nimi kontraktu psychologicznego nie oznacza, że sprzyjają one efektywnemu działaniu, zwłaszcza że w nowocześnie zarządzanych firmach dąży się do rozwijania pracy zespołowej i kreatywności. Według M. Wellina (2010) właśnie dlatego obecnie system pracy kieruje się $\mathrm{w}$ stronę reguł partnerskich, właściwych dla kontraktu psychologicznego transakcyjnego. Tymczasem wymienione przez badane grupy paternalistyczne reguły i zasady wskazują na kontrakt psychologiczny relacyjny, co ogranicza ich skuteczność.

\subsection{Wnioski}

Przekazywanie wiedzy menedżerskiej powinno obejmować nie tylko aspekt formalny, ale także związany $\mathrm{z}$ relacjami w środowisku pracy, determinujacymi efektywną aktywność ekonomiczną firmy. Pracownik i przełożony mogą osiągnąć sukces, jeśli będą tak samo pojmowali istniejące między nimi reguły i zasady współpracy zawarte w kontrakcie psychologicznym. Edukacja ma za zadanie przekazać je tak, aby pomagały obu stronom porozumieć się i podejmować działania sprzyjające realizacji celów biznesowych. Obecnie system 
pracy zmierza w kierunku relacji między pracownikiem a pracodawcą, opartych na regułach kontraktu psychologicznego transakcyjnego. Sprzyja to bowiem pracy zespołowej i innowacyjności. Zadaniem edukacji menedżerskiej jest więc uczenie tych reguł tak, aby wszystkie podmioty rynku pracy mogły efektywnie ze sobą współpracować.

\section{Podsumowanie}

Analiza relacji pracownik-pracodawca z wielu perspektyw wyraźnie pokazuje wzajemne niedopasowanie wyobrażeń o pełnionych rolach. Jest to poniekąd naturalny dysonans wynikający z różnic wieku, miejsca w społeczeństwie, pełnionych funkcji, doświadczenia i innych czynników. Zdaniem autorek różnice te jednak nie muszą być aż tak widoczne. Można je niwelować za pomocą dobrego dostosowania programu edukacji do rozwoju studentów, a później pracowników. Istotne są tu zarówno program merytoryczny, jak i sposoby kształcenia, które pozwola zbliżyć wyobrażenia stron do sobie nawzajem.

Współcześnie przy tak szybko zachodzących zmianach w obszarze edukacji uczelnie muszą działać, nie tylko wsłuchując się w sygnały z otoczenia i reagując na nie, lecz także funkcjonując jak systemy otwarte (Kostera, 2013). Powinny kształtować rzeczywistość i wpływać na nią, a nie tylko wspomagać rynek. Odpowiadanie na potrzeby studentów powinno tylko w uzasadnionej części wpływać na cele strategiczne uczelni, a nie je w pełni determinować (Wieczorkowska i in., 2012).

Tym, co uderza w zaprezentowanych badaniach, jest różnica pomiędzy dość zgodnym $\mathrm{z}$ wyobrażeniem pracodawców podejściem do rynku pracy studentów pierwszego roku (ciężka praca, znaczenie pracy grupowej, asymetria relacji), a zdecydowanie negatywnym i rozmijającym się z wyobrażeniem pracodawców podejściem studentów ostatniego roku (nienegocjowalna dominacja pracodawców, paternalizm w relacjach, wzajemne negatywne nastawienie stron relacji). Oznacza to, że w procesie edukacji biznesowej oraz wraz $\mathrm{z}$ nabywaniem doświadczenia studenci tracą obiektywizm w podejściu, które staje się nacechowane negatywnie emocjonalnie. Przyczyny tego zjawiska należy analizować, pogłębiając badania tego obszaru. Można jednak pokusić się o wyciagnięcie wniosków z zebranych już danych. Jednym z pomysłów powinno być dalsze zbliżanie studentów do rynku już w trakcie studiów innymi sposobami niż dotychczas sprawdzone. W tej chwili realizacji tego celu służą praktyki i staże, których oferta jest w różnym stopniu rozwinięta na poszczególnych uczelniach, a także spotkania studentów z przedstawicielami biznesu. Prowadzone są wszelkiego rodzaju warsztaty dla studentów, które uwrażliwiają ich na relacje tworzące się w różnych obszarach rynku oraz zmiany zachodzące stale $\mathrm{w}$ biznesie międzynarodowym. Nasze badania dobitnie pokazują, że system ten się nie sprawdza do końca, a rozwiązań należy poszukiwać w znacznie szerszym kontekście. Kolejnym pomysłem może być zrzeszanie studentów w grupach tematycznych, w których różnymi środkami mogą pogłębiać swoje zainteresowania. Obecnie uczelnie często pomijają kwestię integrowania studentów, dzięki któremu mogliby wymieniać się doświadczeniami i spostrzeżeniami, tworzyć relacje i grupy wsparcia, czy próbować wspólnych działań. W naszej kulturze, o silnych korzeniach propartnerskich, coraz częściej stawiamy na działania protransakcyjne, które często wymagają o wiele większego wysiłku w dotarciu do celu niż działanie kolektywne (Hofstede, 2000). W zasadzie powyższe przykłady zbliżania do siebie studentów i rzeczywistości biznesowej, która czeka ich po ukończeniu studiów (lub już w trakcie ich trwania), można już odnaleźć na różnych polskich uczelniach. Z badań autorek wynika jednak, że nie działają one w wystarczającym stopniu lub że istnieje potrzeba stworzenia kolejnych środków zaradczych.

Znacznie głębszym problemem jest nadmierna specjalizacja oraz unarzędziowienie edukacji menedżerskiej, która z pozoru zdaje się ułatwiać przyszłą pracę absolwentom, jednak w rzeczywistości mocno zawęża horyzonty studentów. Brakuje na uczelniach miejsca i czasu na rozwijanie wyobraźni i podejścia uwrażliwiającego studentów na otaczająca rzeczywistość (Weick, 2006; Mills, 2007). Wraz z wejściem absolwentów na rynek powoduje to ich zagubienie i rozbieżności wykazane w badaniach. Odwołując się do zjawisk omówionych w pierwszej części artykułu, należy zastanowić się nad zasadnością powszechnego studiowania w kontekście realnej potrzeby 
tak licznej grupy absolwentów uczelni o profilu biznesowym. Należy także świadomie rozważyć problem transformacji współczesnych polskich uczelni, które zmuszone były zmienić tradycyjny porządek uniwersyteckich wartości (społeczne, kulturowe oraz ekonomiczne) i obecnie wydają się sobie $\mathrm{z}$ tym nie radzić.

\section{Przypisy}

1 Wprowadzone rozróżnienie ma na celu zwrócenie uwagi na stan faktyczny, lecz w niniejszym tekście dla uproszczenia będziemy pisać o uczelniach wyższych ogólnie, zamiennie używając nazw.

2 Jest to podejście diagnostyczne zbliżone do tego, jakie wykorzystywane jest w marketingowych badaniach konsumenckich, np. Maison (2000).

3 Przykładem wykorzystania tego podejścia badawczego są badania Sargent i in. (2011).

4 Więcej informacji na temat narzędzia diagnostycznego można znaleźć się w innych opracowaniach (Pawłowska, 2006; Pawłowska, 2012). Wyniki niniejszych badań są analizowane z wielu perspektyw (stanowią cykl publikacji) i były już częściowo wykorzystane przez autorki w: Pawłowska i Postuła (2014).

5 Potwierdza się to w innych badaniach, np. Górniak (2013).

\section{Bibliografia}

Adamska, K. (2011). Kontrakt psychologiczny w organizacji - Kwestionariusz Kontraktu Psychologicznego. Psychologia Spoteczna, 63(18), 267-283.

Argyris, C. (1960). Understanding organizational behaviour. Homewood, IL: Dorsey Press.

Banaszak, S. (2011). Edukacja menedżerska w spoteczeństwie wspótczesnym. Studium teoretyczno-empiryczne. Poznań: Wydawnictwo Naukowe UAM.

Hofstede, G. (2000). Kultury i organizacje. Zaprogramowanie umystu. Warszawa: PWE.

Górniak, J. (red.) (2013) Mtodość czy doświadcze nie? Kapitat ludzki w Polsce. Raport podsumowujący III edycję badań BKL z 2012 roku. PARP, Warszawa. Pozyskano z: http://bkl.parp.gov.pl/ 10 października 2013 r.

Kostera, M. (2003). Antropologia organizacji. Warszawa: Wydawnictwo Naukowe PWN.

Kostera, M. (2010). Organizacje $i$ archetypy. Warszawa: Wolters Kluwer Polska.

Kostera, M. (2012). Etnografia ról kierowniczych. W: M Kostera (red.), Szef polski. Studia przypadku o roli kierownika $w$ organizacjach (s. 13-26). Warszawa: Wydawnictwo Akademickie Sedno.

Kostera, M. (red.). (2013). Organizować z polotem. Wyobraźnia organizacyjna $w$ praktyce. Warszawa: Wydawnictwo Akademickie Sedno.

Koźmiński, A.K. (2011). The new revolution in management education? Master of Business Administration, 4/111, 2-6.

Kwiek, M. (2015). Uniwersytet $w$ dobie przemian. Instytucje i kadra akademicka $w$ warunkach rosnacej konkurencji. Warszawa: Wydawnictwo Naukowe PWN.

Leja, (2013). Zarzadzanie uczelnia. Koncepcje i wspótczesne wyzwania. Warszawa: Wolters Kluwer Polska.

Maison, D. (2000). Zogniskowane wywiady grupowe: jakościowa metoda badań marketingowych. Warszawa: Wydawnictwo Naukowe PWN.

Makin, P., Cooper, C. i Cox, Ch. (2000). Organizacje a kontrakt psychologiczny. Zarzadzanie ludźmi w pracy. Warszawa: Wydawnictwo Naukowe PWN.

Mills, C.W. (2007). Wyobraźnia socjologiczna. Warszawa: Wydawnictwo Naukowe PWN.

Mintzberg, H. (1973). The Nature of Managerial Work. New York: Harper and Row.

McInnis, K.J., Meyer J.P. i Feldman, S. (2009). Psychological contracts and their implications for commitment: A feature-based approach. Journal of Vocational Behavior, 74, 165-180.

Morgan, G. (1997). Obrazy organizacji. Warszawa: Wydawnictwo Naukowe PWN.

Morgan, G. (2001). Wyobraźnia organizacyjna. Warszawa: Wydawnictwo Naukowe PWN.

Pawłowska, A. (2006). Badanie relacji społecznych w organizacji z wykorzystaniem metod projekcyjnych. Studia i Materiaty, 3(3), 7-17.

Pawłowska, A. (2012). Projective methods in diagnosing an individual's cognitive map of occupations. W: B. Mróz (ed.), Functioning in the workplace. Quantitative and qualitative psychological research (s. 115-127). Warsaw: Wydawnictwo Naukowe Scholar.

Pawłowska, A. i Postuła, A. (2014). Pracownik i pracodawca - wykorzystanie technik projekcyjnych w badaniu postrzegania wzajemnych relacji. Problemy Zarzadzania, 12(1), 30-49.

Sargent, L.D., Bataille, Ch.D., Vough, H.C. i Dea M. (2011). Metaphors for retirement: Unshackled from schedules. Journal of Vocational Behavior, 79, 315-324.

Shaw, M.M. (2013). Impacts of globalization on the academic profession: Emerging corruption risk in higher education. W: Global corruption report: Education (s. 194-201). New York: Routledge-London: Transparency International. 
Weick, K.E. (2006). The role of imagination in the organizing of knowledge. European Journal of Information Systems, 15, 446-452.

Wellin, M. (2010). Zarzadzanie kontraktem psychologicznym. Zaangażowanie pracowników w zwiększenie wydajności firmy. Warszawa: Wolters Kluwer Polska.
Wieczorkowska, G., Wierzbiński, J. i Michałowicz, B. (2012). Wyzwanie dla zarządzania edukacja: odmitologizowanie przyjmowanych bezrefleksyjnie założeń. W: A.P. Wiatrak (red.), Aktualne problemy zarzadzania - teoria i praktyka (s. 63-79). Warszawa: Wydawnictwo Naukowe Wydziału Zarządzania UW. 